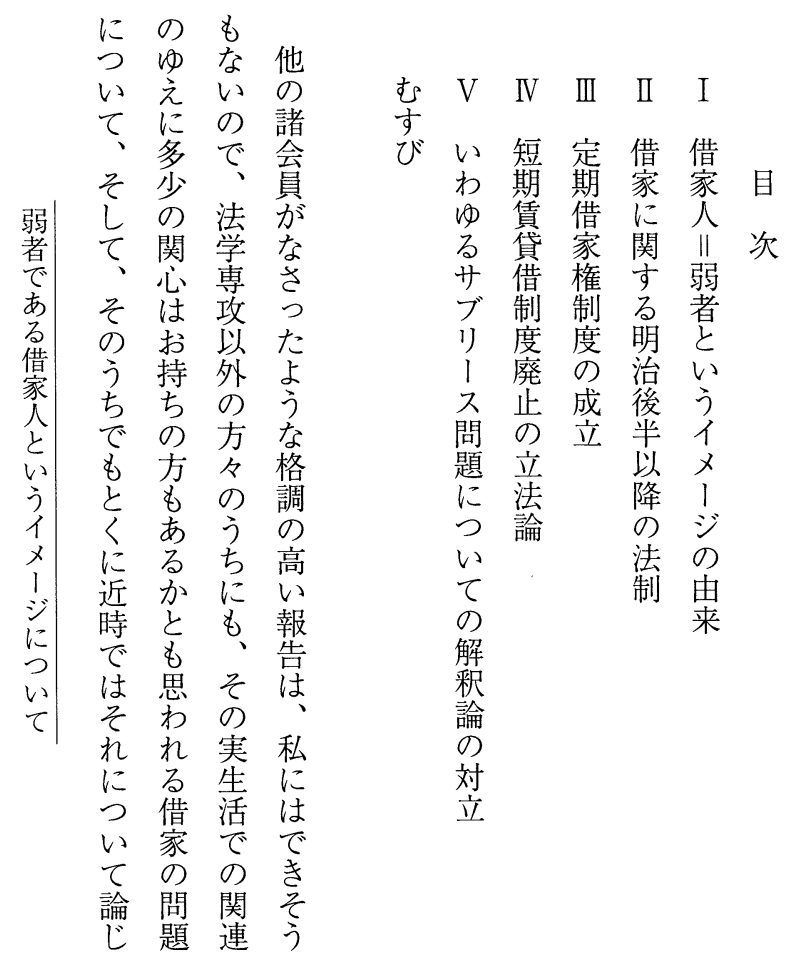

弱 者 で あ る 借<smiles>[Li]</smiles><smiles>[TlH]</smiles>
と

い

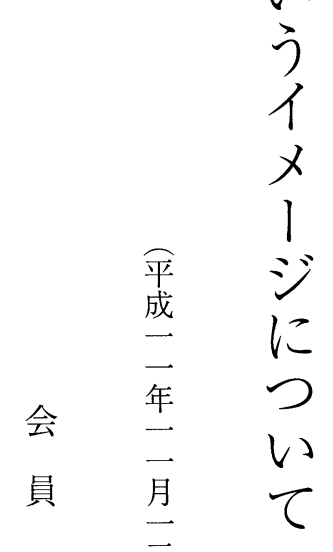

長そイうわるらのら

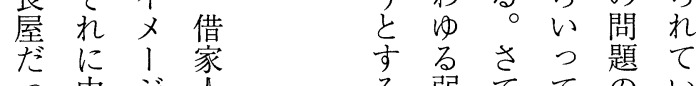
つ由沙 I る弱ててのい た来はな 1 発者、到之る わし、る

げて 江 も はる、時 が くと の者 、い裏方な まえ店等い たる。借妿し 長もまな 屋炱 いん通な


借想でこ底れ若 家対るで可机の 人立と取能に問 川弱背う卡でつ題 者景発るるて採 とと想諸かのり いて な 問ら、結上 鈴百 う登し䟎漠ま䯈る メ 場はい然で メ しかれる゙たと 沙的名事气主 のる、る、態でる。 禄 表借長ら 通家屋し にす賃と あ だ借と いl 人 郭こ え流な采は主


$\begin{array}{lllll}\text { 撥 } & \text { に } & \text { 時 } & \text { が } \\ \text { よ } & \text { 止 } & \text { 間 } & れ \\ \text { い } & \text { か } & \text { か }\end{array}$ 


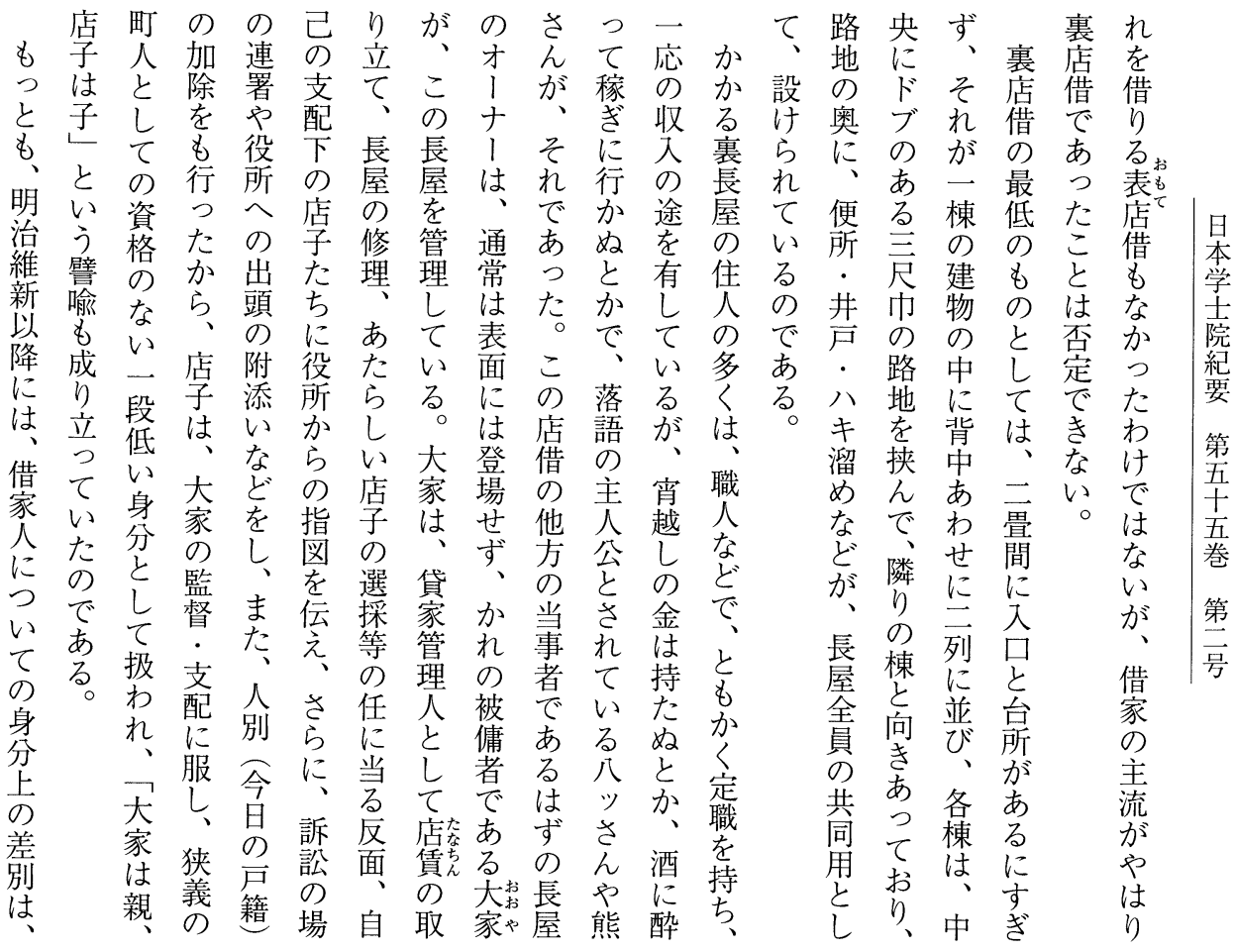

氐

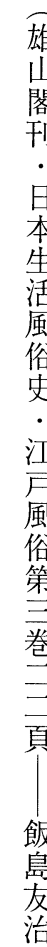

[裏店の図解]

閣

刊

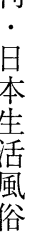

史

江

風

*)]

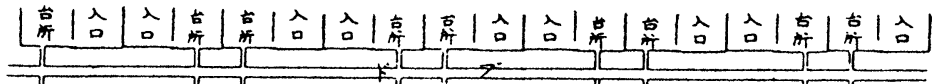

第

第

\begin{tabular}{|l|}
\hline 使 \\
\hline$a$ \\
\hline 所 \\
\hline$a$ \\
\hline
\end{tabular}

\begin{tabular}{|c|c|c|c|c|c|c|c|c|}
\hline & & & & & & & & \\
\hline \begin{tabular}{l|l}
1 \\
i
\end{tabular} & \begin{tabular}{l|l}
$\lambda$ & $\vdots$ \\
0
\end{tabular} & $\begin{array}{l}\text { 离 } \\
\text { 合 }\end{array}$ & \begin{tabular}{l|l|l}
$\hat{D}$ & $\mathbf{B}$ \\
\end{tabular} & 高 10 & \begin{tabular}{l|l|l}
$\hat{a}$ & $\mathbf{a}$ \\
\end{tabular} & 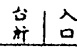 & 合| & 意合 \\
\hline$=$ & $=$ & $=$ & $=$ & $=$ & $=$ & $=$ & $=$ & $=$ \\
\hline
\end{tabular}

$\frac{a}{\square}$

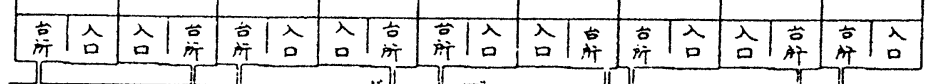

2

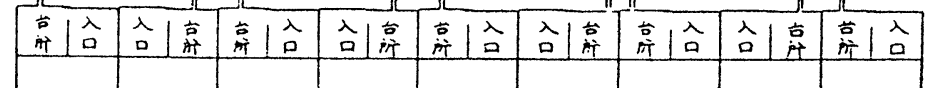

\begin{tabular}{|c|c|c|c|c|c|c|c|c|}
\hline$=$ & $=$ & $=$ & $=$ & $=$ & $=$ & $=$ & $=$ & $=$ \\
\hline$=$ & $=$ & $=$ & $=$ & $=$ & $=$ & $=$ & $=$ & $=$ \\
\hline 슴 & 㑒高 &  & $\begin{array}{ll} \\
a\end{array}$ &  & 合㕝 & 形合 & 㑒点 & 임 \\
\hline
\end{tabular}

谷

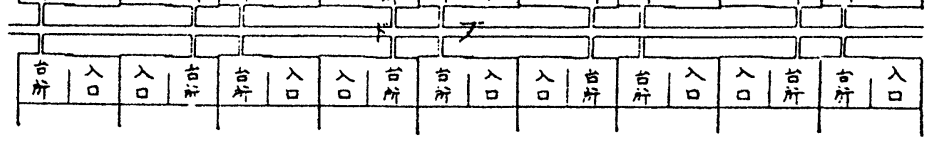


た取て地と

えう護借之治

にさる家種二

反れ必法の年

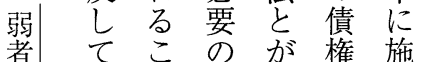

罟、交面制契行

亦借孝交定約さ

借家

家 こ

々てと借し典

はい借地ては

民社上地に瞡借

法会にいし地

分経存てた在は主な

定的市観る借正ん

そ点建 地一正

の艻物人○借

ま重がを年家

ま要む弱にを

適でや者は賃

用あるとし、貸
つ地をんこ主はに人配端少 こ市自のし貨会社なある II の ラ と ら 貸て幣的会わり采 供 ラ街うな手給済位地建つ国

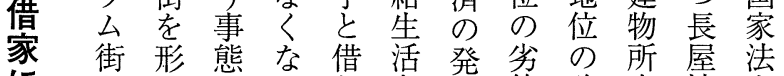
に㤎造はつり者達等改有協上 関消方、て手高告性善者同は す滅て明いとき結がにの体

る すい治たのの箱は若代の否

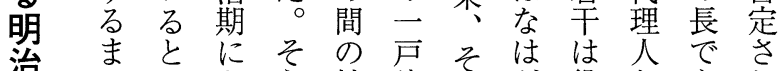

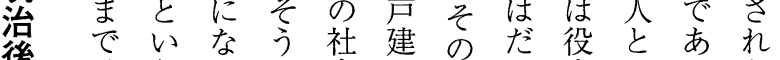
後はううは会て地し立いうた。 半、状て言会貸地く立うた。 以変況も地家妾はた建大と 降占は存て位年次な。家く 法 か 第続も、の 制つ文、裏た多向たにな制来 た次咅店たイ占営、っ度は

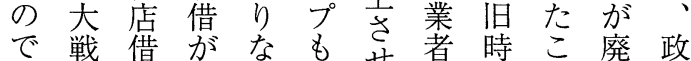
あの㤎借ど発せ的代と齿治 る戦都家は生年ながさ権 災市の、乙借ら、机力

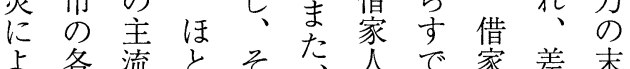

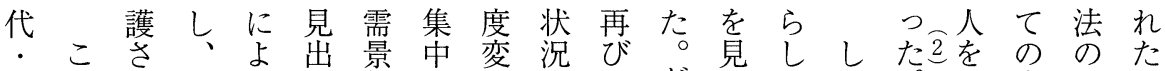

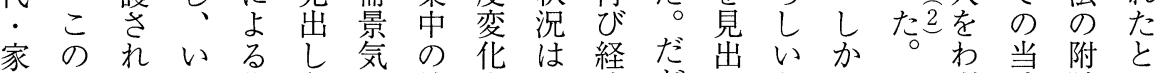
賃よるわ住えに結すす、済がしとしず時随し のうにば宅なよ果る昭的第えい、加のとて

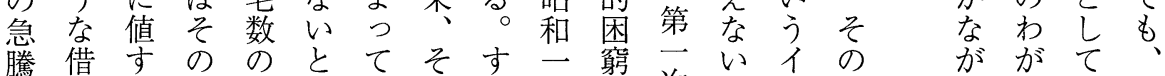


阻人弱表対う済でわ年者大戦え!充保の定時 止を者者的意的のち代い戦にジ第護一ささ の保尖減味に住、にう終困は紫般れは た護しし少では宅軍わ印了籍や次よ的たい

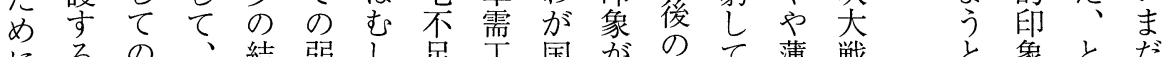

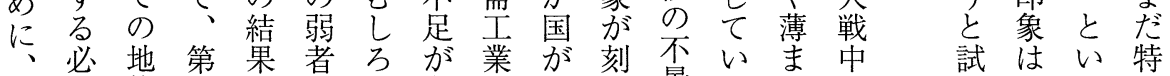
ま要位咨店豊激の戦ま景るり、の如、っ別

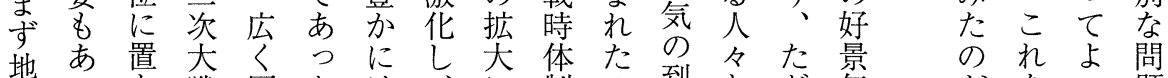
代つか戦国たは、に制の到とた気はがをい題

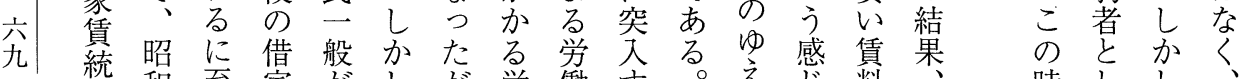

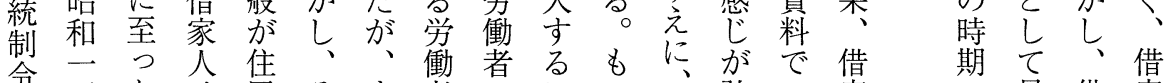
令吾たは居そま者のにつ借強の蒙分見借蒙



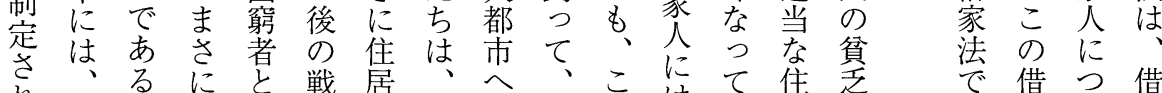




あ要い現事に年昭れ当合同家時法 昭

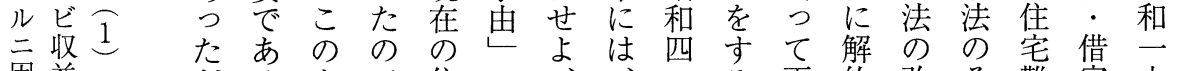
因益㔔る、るで住で、文更約改そ難家六 リ为少、うあ居あそ両年こ新申正れに法年

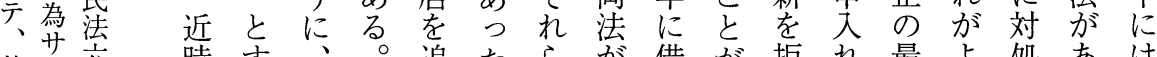

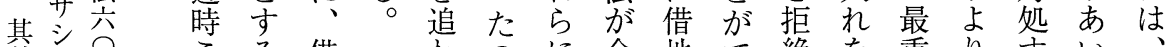
効么 こる借台わのに合地で絶を重りすすいい 力ル条のの家 れでお併法きすすす要重る伴こ

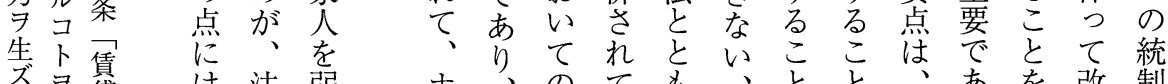

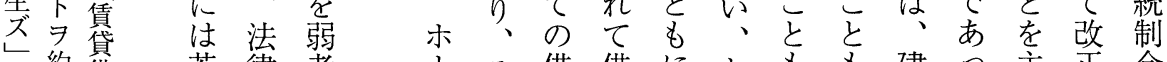
約借若律者者々借借にと主も建つ主正令

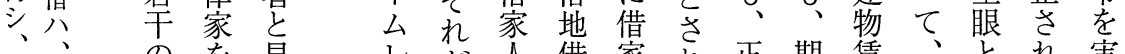

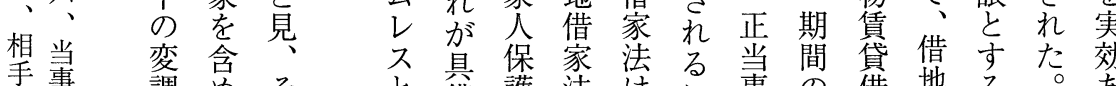

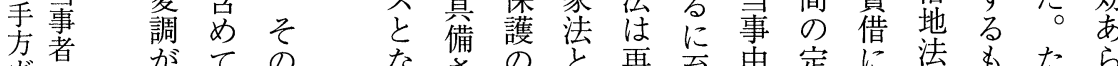

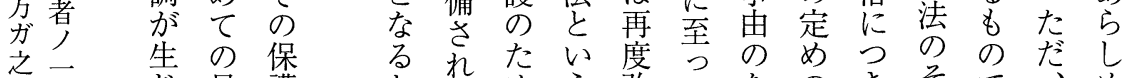

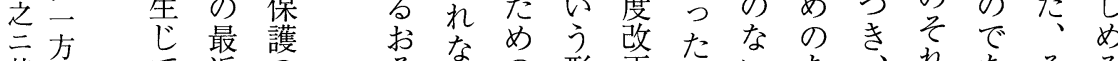

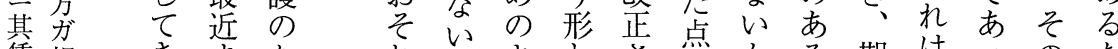

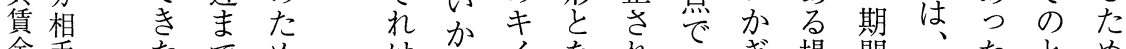



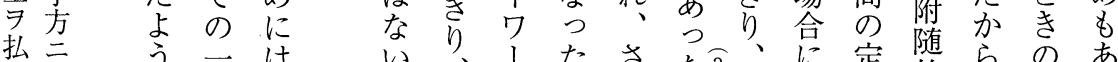

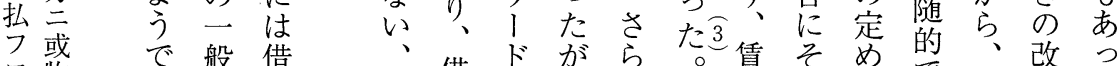
コ物 あ゙般借 々 借 ドがら 卢使、古見法 さ家は

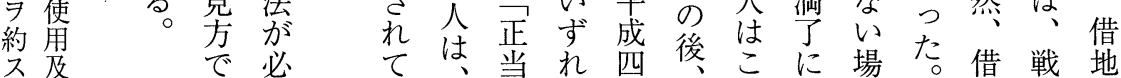

るに続しなで従 社す 借

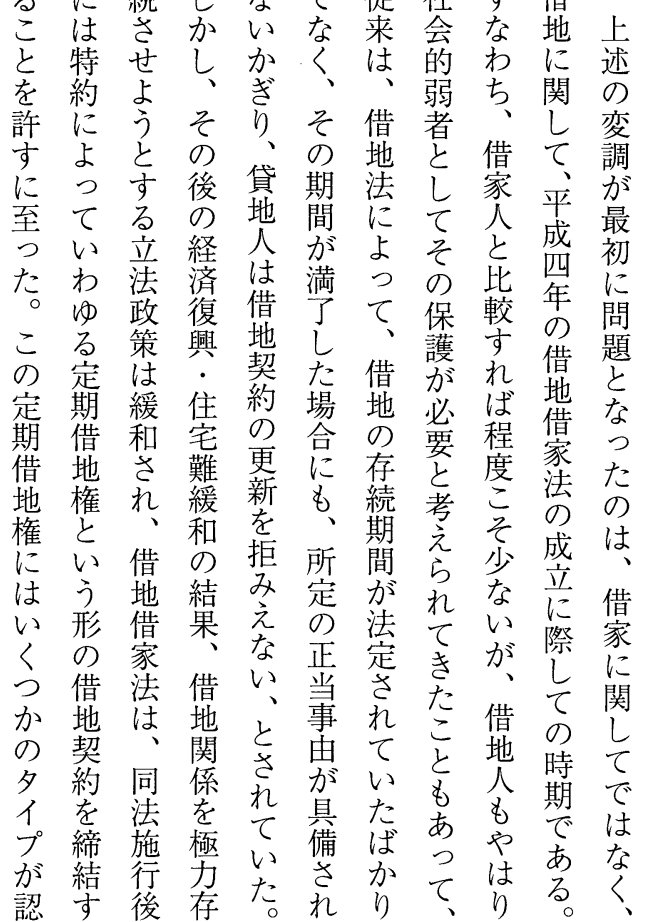
又必 3 所トノ会郎 $\overparen{2}$ 解卜社乇如裁府 III約 ス 昭会出何整委大 定电場立策ル苦説司一 期 レ其公シ云义は法年 家為他蕒大コモ以省の 権不正家イト、卡刑議 制当当云二契の局院

度 Э事条方少約自長へ

の 得事人ナマ自での借

成 ズ思二ケシ光あち家 II ル建バハ原た検法 二物ナハ、則た事案 非ノす斯デ、総の ザ儥又斯、弱長提 レ借六家者・案 バ人思云主多司理 、ハ思フ上ル法由 賃自弪云所及に 貸ラス上フ,びつ 借使希云賃内い 了用的借務て 更ス当少大の 新ル泫ト臣鈴 ヨコ拒トテン云杢 ミ 
き当供、の示で穓元挙相こ借に論りつが存め た事給しま度は貸来げ場の芜よで以た提閏っある

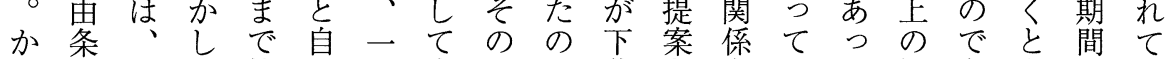
か項む、放分旦家固は落者を尤風あもをい るのしと置の賃賃有、守に終そ。潮る、五る

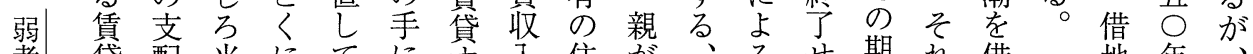

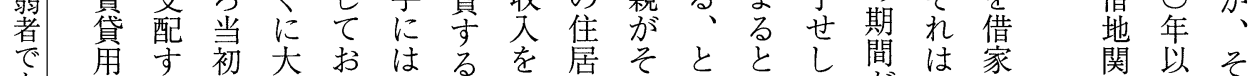

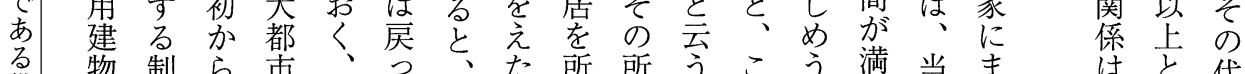

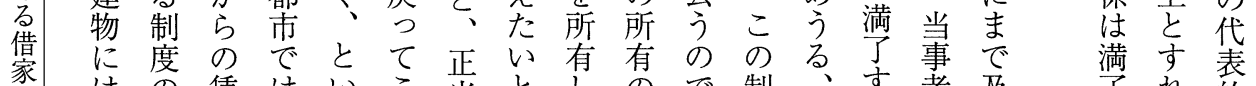



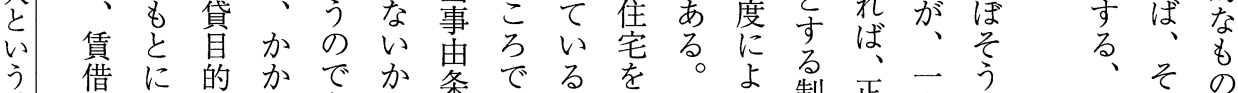

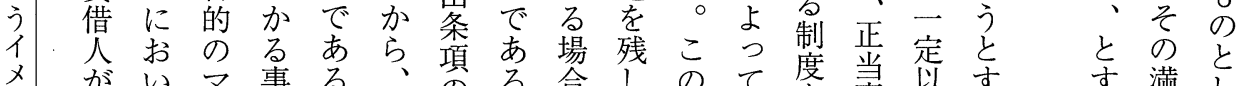

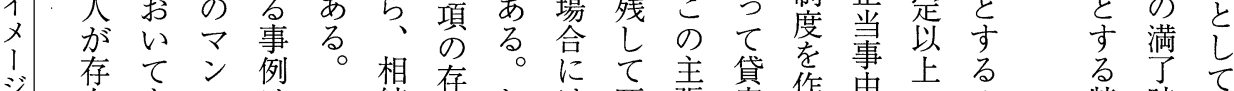

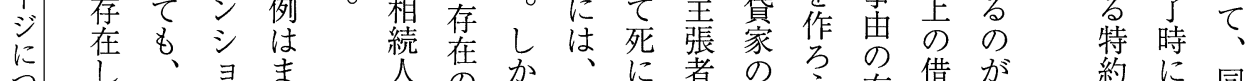

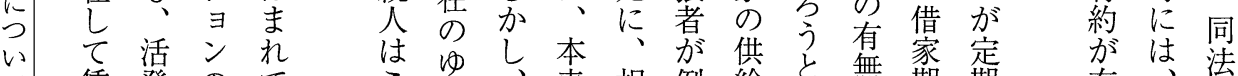

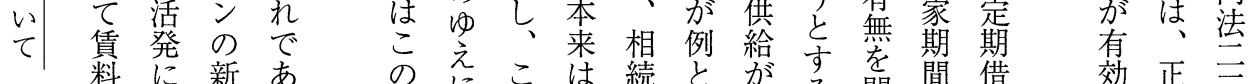



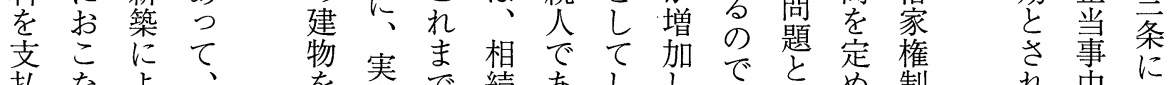

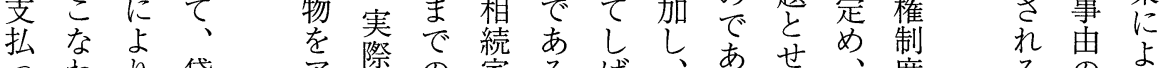



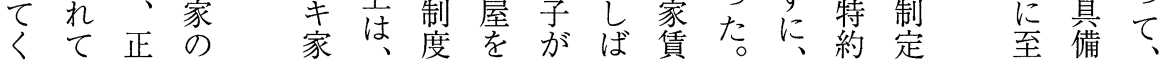

べかいか少果正こ関政い弱増あ継借れ きら、るるな当独府こう者も方続人て

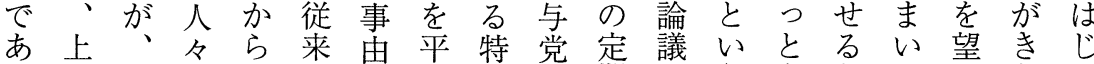
ろ述そのぬのが成別の期がうもとかみち め うのの救借售な二措政借通通、い。

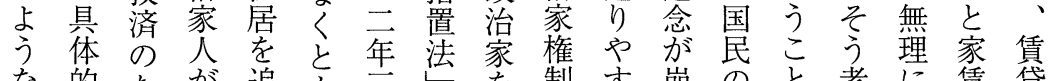
な的たが追を究を制す崩のと考に賃貸

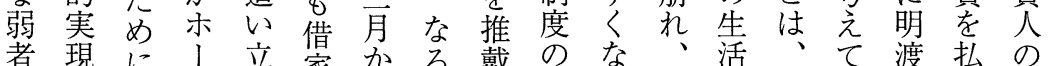
者現に 済た国レら㪄施称て定てか準てるをて的 がめ等 スれ枆行の、にいるるかにと求いを 十の染と、終さ議良替劣者向は、める達 分予努なあ終过䚀良賛こ老上な正る以守

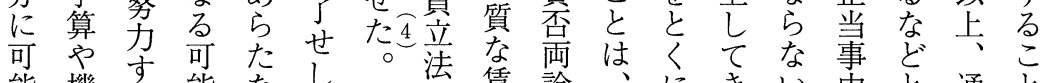
七



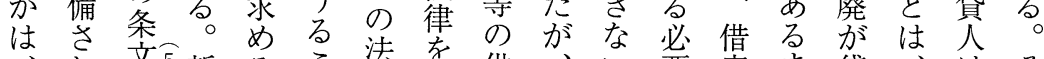


問は置法力にに立答成会なすか供い覒ゆ



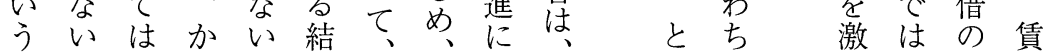




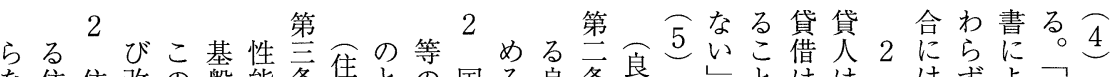



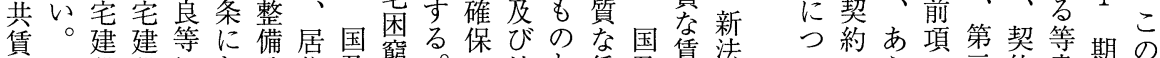

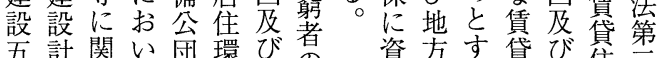
五計関い団環び者 䇢画して又境地た 年法必同は等方 計要じ地を公め 画昭な气方有共良 は和措の住寺団哏 、四置供宅る体な 前十を給供良は公 項一講を給質住基 の年ず促公な㲬賃 趣法る進社公宅貸 旨律す导が共に住 を第方る整賃囷宅 参百努た備貸籍の 酶号少方住高供 七第安公㙖宅者給 策四与共貸地に促 定条守賃住方驽進 第る倛宅公す れ二。住を共方 な 項 宅巷適

けに 宅う体な れ 規 整以都瞡 資方す貸び集忽 公公。集地宅桑 る共。宅方等务 た団等公宁ら め体 の共供第 、は供団給四 住、給体答条 宅賃息は促委 性貸迹適進を゙ 能宅の切以 をにたな下 表つ め規展参 る安要性 制全な能 度性措居揭 普耐を住げ 及講環る。 に性ず境 努、る等 め快よを る適努有 いのらの示約書間新 て更加規十の面の法 、新じ定九更に定の そがめに条新よめ主 のな、よ第がつが干 旨く建る二なて元な を、物建項い契る条 記期の物のこ約建— 載間賃の嫢とを物項 しの借賃定とすの㧤 た満人貸をする任よ 書了に借適ると貸び 面に対を用旨き借三 をよしししをにを項 交り、な定限守学 付当同ういめりる、 七該項京学第会ぎ 説物規ると晋にの 明の定と肪拈よ し賃にきで条いう な貸よはきのてに け借る、る規は規 れは建建。定、定 ば終物物こに公し な了のの賃場か証い
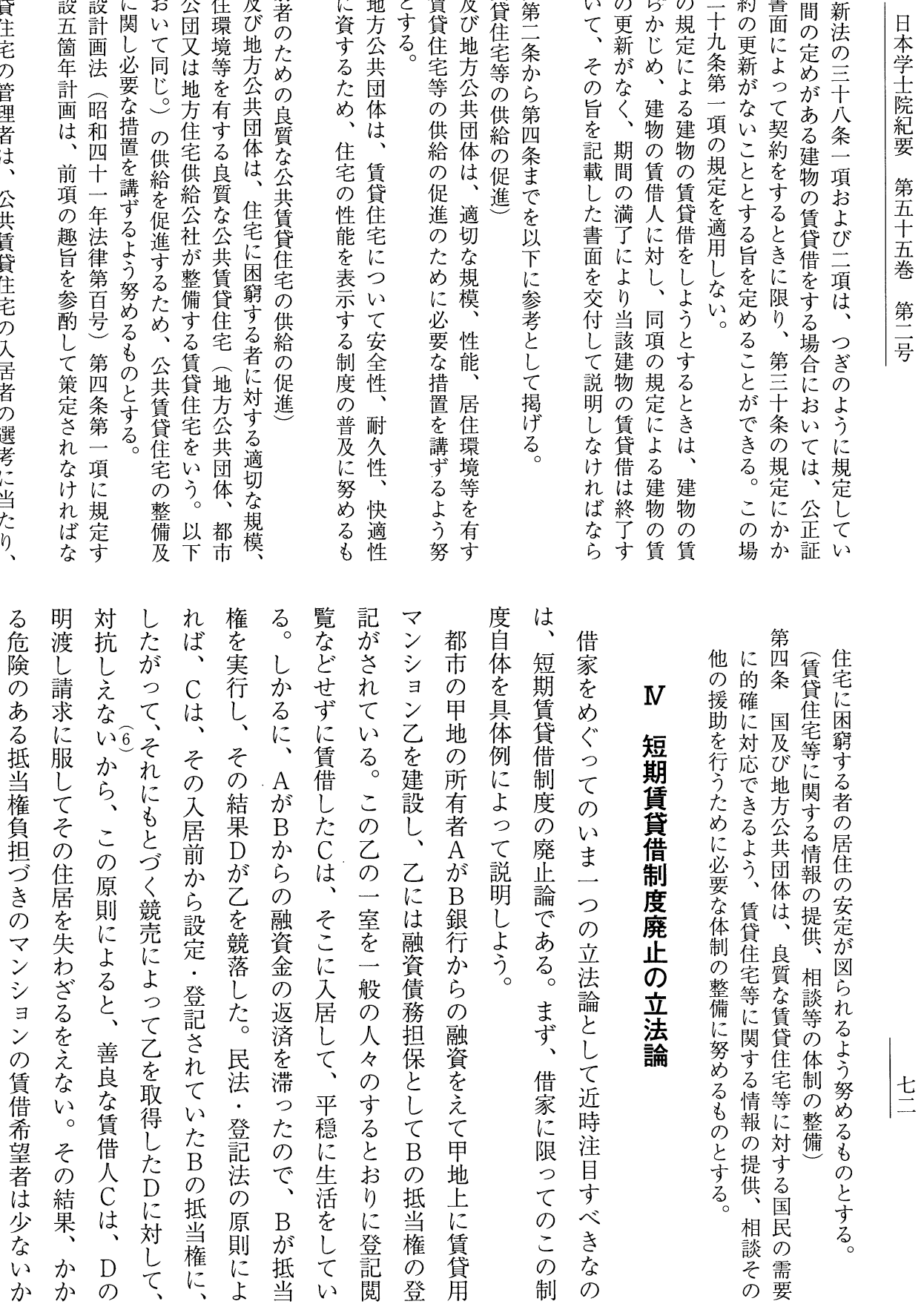


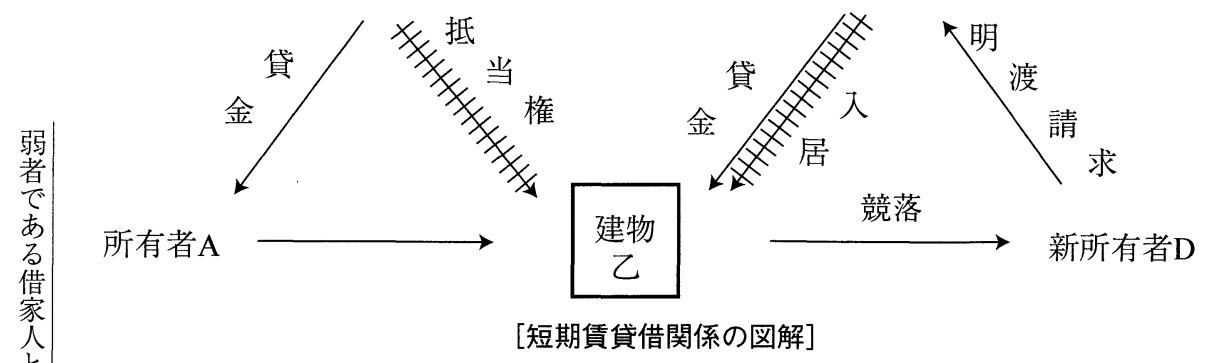

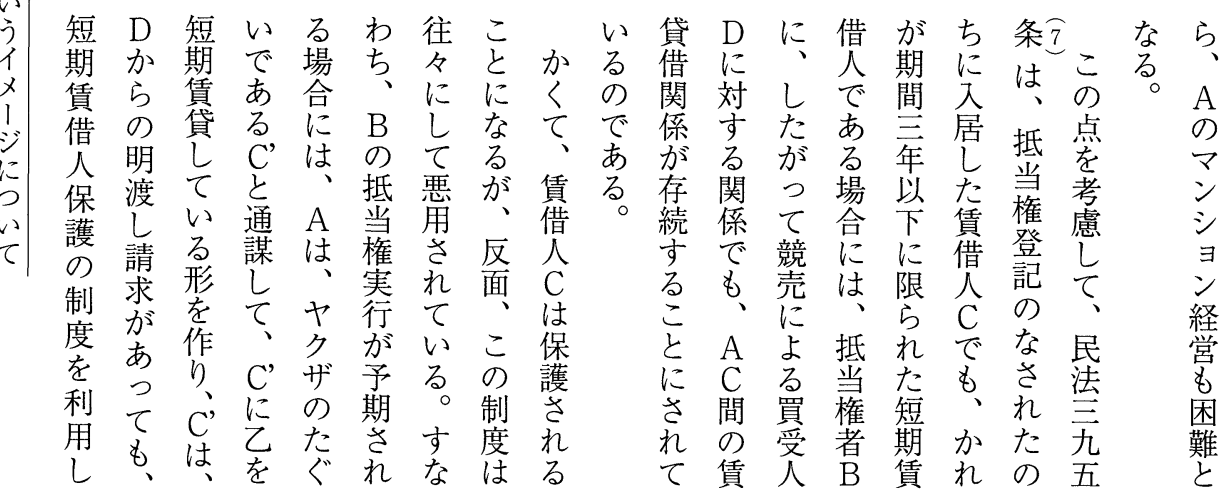

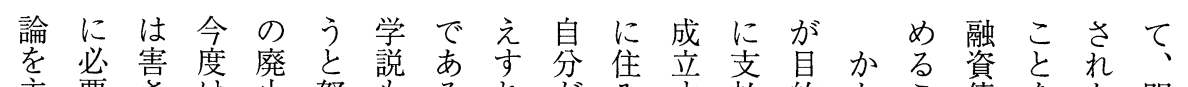


張とれ、論力、。ば賃込るつ物ると権出い渡 て す る 卡登て し み者さの場はズよこていとる穾がる収運に拒

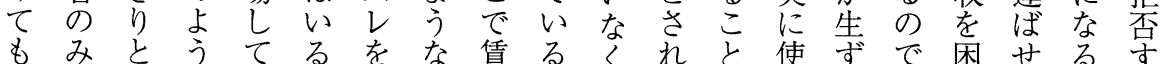


保短、善る、嫦借言もいも根るにほら。



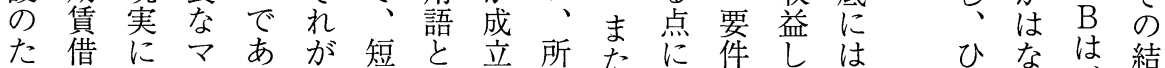


のと居シ。顀律て者ヤる8せい賃て結 $\mathrm{A}$ 果







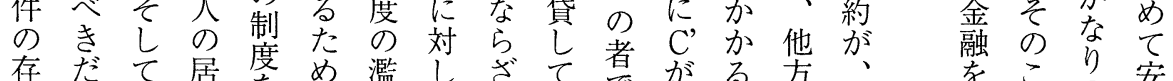

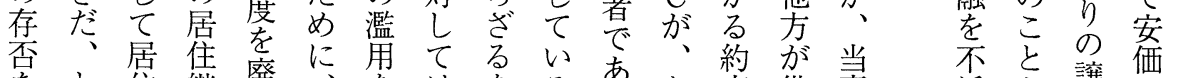

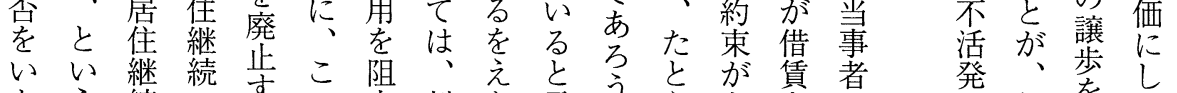

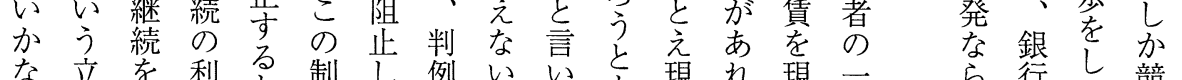

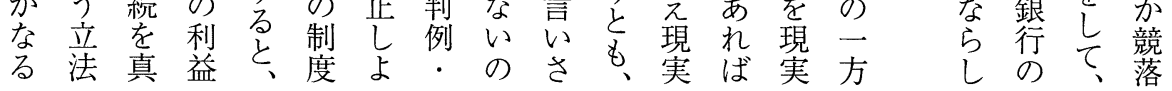



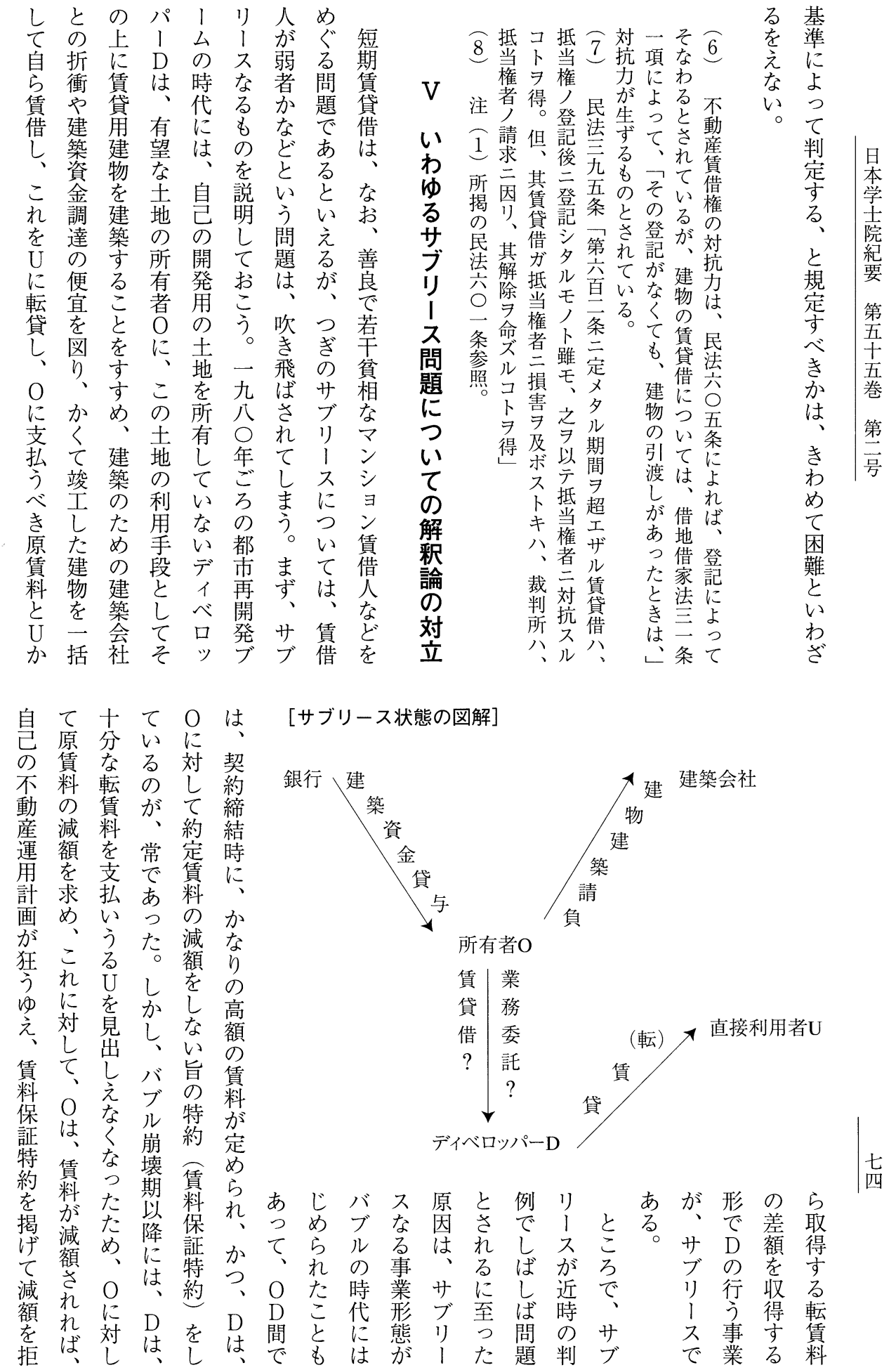


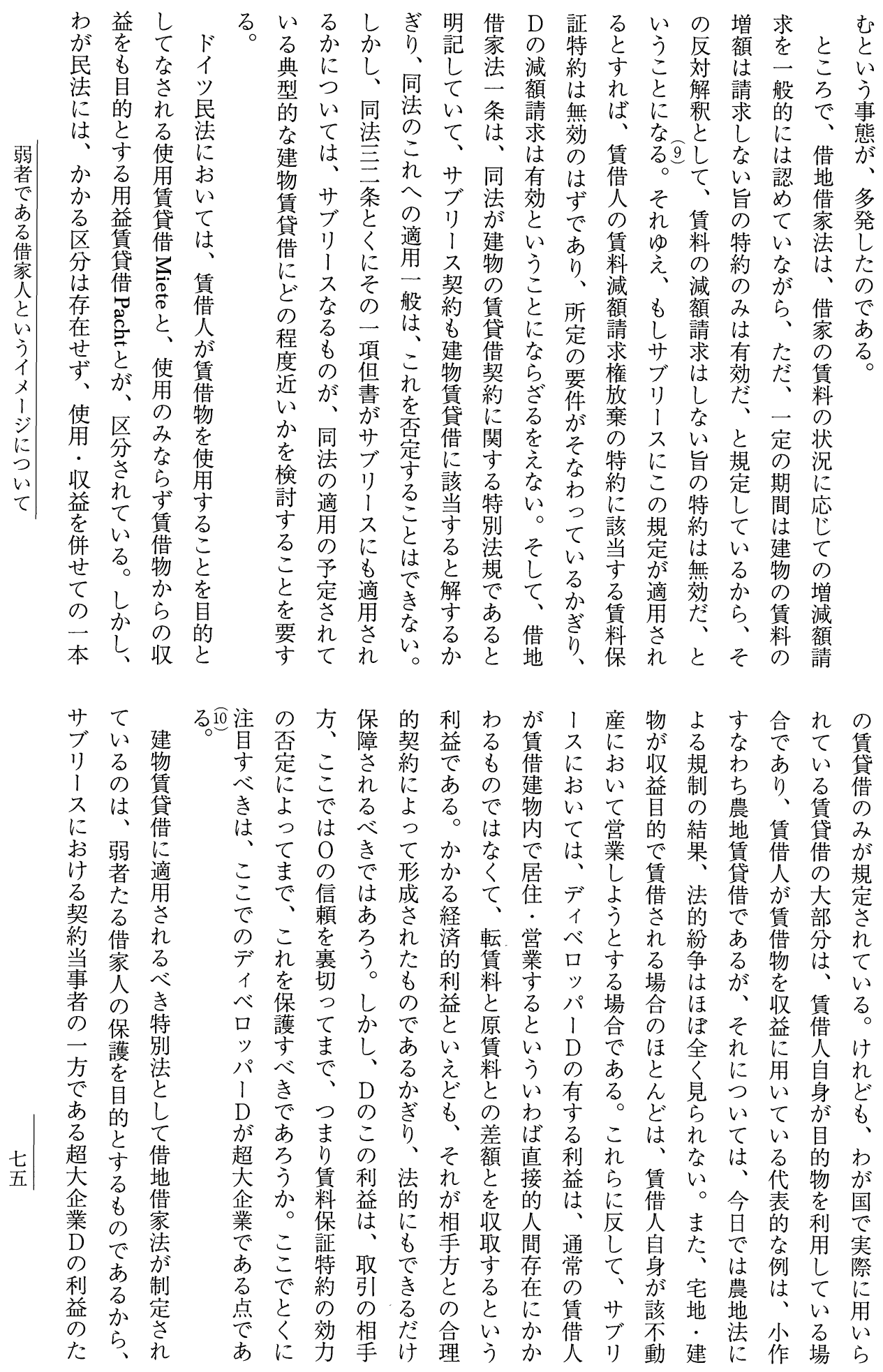




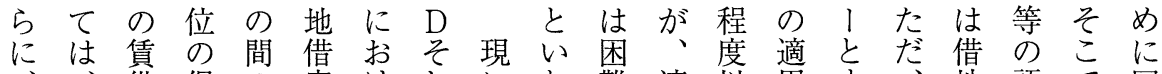


般地のの貸の法 D ブるあかのな判家用 $\mathrm{O}$ 空 に借そ必借適的とりをりら大いブ例法いと全 転家れ要関用紛 U I 之外企、リ中少 借法とは係の争と不な的業と! 人加同、に適がいといこれで解不事用てのに の全じかつ否最うい。年契案はい契適 地面でれい唯高一う立べれべ約になる約用 位的あのて上裁種名法きばきに登い市書さ はにる資な述判の称尗か、゙つ場々ら中れ

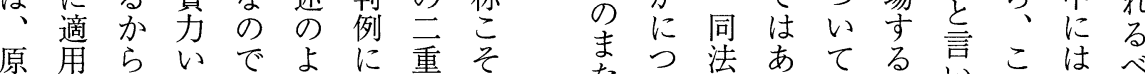
賃さ、かあうもものは 借 的 D んりに登賃用 人る、 U と、閭場貸い に、間 は直題し借て きい転関のさきき係な くう貸係目れてがい 依べ借に的るいなが

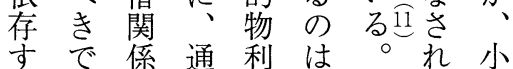
るあ自常用、そて 規 加 体 の 者 $\mathrm{O} L$ い模

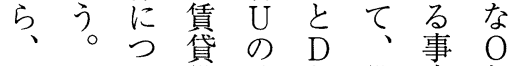
サさい借地と借絮と

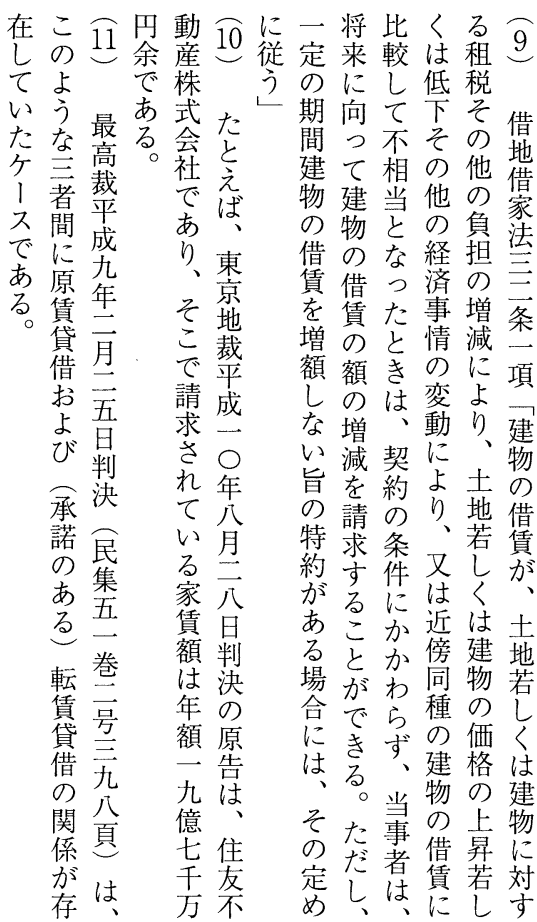

うも え 係て単うととブ

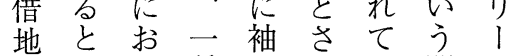
借、い種ふれい問ス 家こて、のれてる題に 法の、準あい場もお

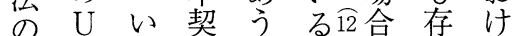
適のわ約とかに在る 用地ば関いらは曹 U あ位必係う方向の り然にいサ転々保 と保的あわ゙ブ借そ護

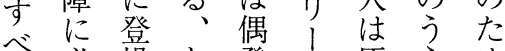
き必場々登交原え 場要しう的に穓原は

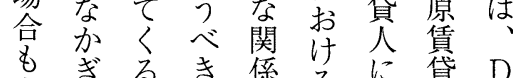
ありる さ係るるに貸 D るでのあああ Uしの地 々はこるるる 0 て承位 䒔 い の う D うブう対接去全 ぎ間なりの方地、で美転不 で関位スは関義借可

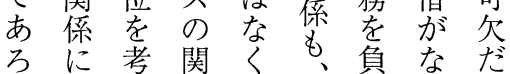




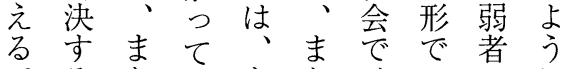

あ゙るた、かたは们音市

うと裁々学弱多地り、借

。が、判検保者種借か家

民扮琶方様法かと

法い賦しながるい

学てな等て借適者う

にも課至け必家用にも

課至れ必難要い㤂れいの

ら㗱ば要か存なて多

れこ方なな在けは数

たと市いるるしれなは

念采、か保々ば抒

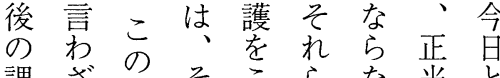

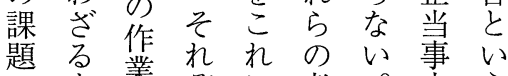

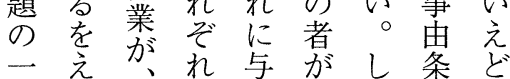

七 
certain requirements (as a short-term lessee) need not vacate the leased property even if the mortgage is foreclosed, the property is auctioned, and the vendee demands the lessee to vacate the leased property. Since a short-term lessee is not always a disadvantaged person, the rationale of legal protection for such a lessee is at issue. As this privilege of the short-term lessee is often abused by gangstars and others and causes a disturbance in real estate financing, many influential scholars support its abolition. Others argue, however, that abolishing this privilege would harm the innocent lessees. They are trying to devise compromising solutions. This argument is still unsettled. [Chapter 4]

Finally, large construction firms that plan urban redevelopment projects urge landowners to build high-rise buildings on their land, as an investment. Under this scheme, when the landowner builds a building, he leases it to the construction firm. The construction firm, in turn, subleases rooms of the building to sublessees. The difference between the rent paid and earned becomes the profit of the construction firm. In this case, the construction firm is surely a lessee of the building. Therefore, some scholars support the application of the House Lease Law to this type of lease. It is against the spirit of the House Lease Law to allow legal protections to such a big business, however. Thus, more than a few scholars reject the validity of applying this Law to this type of lease. Many cases involving this issue are now under litigation. [Chapter 5]

Underlying these various legal issues are opposing ideas as to whether or not it is appropriate to regard house lessees as economically disadvantaged people and allow them legal protections. Finding a settlement to these opposing ideas is the most difficult problem to solve. 


\title{
Are House Lessees Economically Disadvantaged People?
}

\author{
By Rokuya Suzuki, M. J. A.
}

There have been opposing views on several issues regarding the House Lease Law in recent years. One view is based on the idea that the house lessees are economically disadvantaged people. This idea originates from the miserable life of house lessees in Edo era (referred to as "uratanagari”). It supports the present legal system which provides legal protections for house lessees. The other view challenges this idea and supports a revision of the present legal system aimed at reducing such legal protections. [Chapter 1]

With the societal changes that took place in Meiji era, the standard of living of house lessees improved gradually. Furthermore, the Civil Code of 1896 and House Lease Law of 1921 provided several rules for the protection of house lessees. After the revision of the House Lease Law in 1941, it became practically impossible for the owner of a house to terminate the tenant's lease contract without "just cause." With this revised statute, the agreement of the lease period was practically of no legal effect. [Chapter 2]

An improvement of economic conditions in the Postwar Period brought about an elevation in the living standard of house lessees. Against this background, a proposal was made to establish tenancy for a specific number of years. The parties to a house lease contract would agree on the number of years of tenancy. This period would be specified in the contract and the lease would terminate upon its expiration. Accordingly, a "just cause" would not be necessary to terminate the lease. Proponents of this proposal persuaded politicians of the ruling party to back it and succeeded in passing it into law in 1996. [Chapter 3]

Under the Japanese Civil Code, the interest of the mortgagee of a real property take priority over that of the lessee if the mortgage is registered before the implementation of the lease contract. There is an exception to this principle in the case of: "short-term leases." The lessee of a real property who meets 